\title{
Unravelling the foraging behavior of the southern stingray, Hypanus americanus (Myliobatiformes: Dasyatidae) in a Southwestern Atlantic MPA
}

\author{
Renato H. A. Freitas ${ }^{1}$, Aline A. Aguiar ${ }^{2}$, Ana Karina C. H. A. Freitas ${ }^{1}$, \\ Sergio M. Q. Lima ${ }^{3}$ and Jean L. Valentin ${ }^{2}$
}

Previous study suggested that the southern stingray (Hypanus americanus) displays a marked ontogenetic shift in its habitat use in the Fernando de Noronha Archipelago (FNA), an attractive touristic spot in Brazil, that could be associated with changes in its feeding habits and foraging strategies. Here, we conducted underwater visual surveys ( $100 \mathrm{~h}$ a 3 years' study) at this site to describe the foraging behavior of the same species in details and to assess diel patterns in activity. We observed that $H$. americanus is capable of several complex and highly plastic behaviors (we described more than 21 of them) while foraging. The foraging events' timing appears to be related to the size (as well as sex) of the stingrays, environment and depth. In addition, our results support a segregation of habitat mediated by the size and sex of the stingrays, but it is able to modulate its foraging repertoire based mainly on environmental stimulus. Finally, we found that $H$. americanus forage intermittently throughout the day and tidal cycle, yet are less active during non-crepuscular periods and at flood and ebb tides. These results, coupled with the fact that the species uses both reef and beach environments, should be considered by decision makers in management plans.

Keywords: Dasyatidae, Elasmobranch, Feeding habits, Fernando de Noronha, Foraging strategies.

Um estudo anterior sugeriu que a raia-prego (Hypanus americanus) apresenta uma marcante mudança ontogenética no seu uso de hábitat no Arquipélago de Fernando de Noronha (FNA), local turístico atraente no Brasil, que pode ser associado a mudanças em seus hábitos alimentares e estratégias de forrageamento. Aqui, nós conduzimos amostragens visuais subaquáticas ( $\sim 100 \mathrm{~h}$ em 3 anos de estudo) nesse local para descrever o comportamento de forrageamento dessa mesma espécie em detalhes e acessar seu padrão de atividade diário. Nós observamos que $H$. americanus tem capacidade para comportamentos complexos e altamente plásticos (nós descrevemos mais de 21 deles) enquanto forrageia. $O$ tempo dos eventos de forrageamento parece estar relacionado com o tamanho (e também sexo) das raias, ambiente e profundidade. Além disso, nossos resultados apoiam a ideia de uma segregação de hábitat mediada pelo tamanho e sexo das arraias, mas que ela é capaz de modular seu repertório de forrageio baseado principalmente em estímulos ambientais. Finalmente, nós descobrimos que H. americanus forrageia de forma intermitente ao longo do dia e ciclos de marés, mas é menos ativa durante os períodos não-crepusculares e nas enchentes e vazantes das marés. Esses resultados, somado ao fato que a espécie utiliza tanto ambientes recifais quanto praianos, devem ser considerados pelos tomadores de decisão em planos de manejo.

Palavras-chave: Dasyatidae, Elasmobrânquio, Estratégia de forrageamento, Fernando de Noronha, Hábito alimentar.

\section{Introduction}

Hypanus americanus (Hildebrand, Schroeder, 1928), originally named as Dasyatis americana before the review of Last et al. (2016), is a benthic stingray that exhibits solitary foraging (Semeniuk, Rothley, 2008) in coastal shallow waters of tropical and subtropical parts of the Western Atlantic, including tropical oceanic islands such as the FNA (Bigelow, Schroeder, 1953; Menni, Stehmann, 2000; Soto, 2000). This species is an opportunistic predator of lancelets and bivalves (Stokes, Holland, 1992), but crustaceans are the dominant prey item (Gilliam, Sullivan, 1993). Hypanus

\footnotetext{
${ }^{1}$ Laboratório de Biologia de Teleósteos e Elasmobrânquios (LABITEL), Departamento de Ecologia e Zoologia, Centro de Ciências Biológicas, Universidade Federal de Santa Catarina, 88040-900 Florianópolis, SC, Brazil. (RHAF) rhafreitas@gmail.com (corresponding author), Dhttps://orcid.org/0000-0002-9053-9186; (AKCHAF) karinahajenius@gmail.com, @https://orcid.org/0000-0002-0006-6689

${ }^{2}$ Departamento de Biologia Marinha, Instituto de Biologia, Centro de Ciências da Saúde, Universidade Federal do Rio de Janeiro, 21941-590 Rio de Janeiro, RJ, Brazil. (AAA) a_a_aguiar@yahoo.com.br, Dhttps://orcid.org/0000-0001-9461-2216; (JLV) jlv@biologia. ufrj.br, Ohttps://orcid.org/0000-0002-1221-3914

${ }^{3}$ Departamento de Botânica e Zoologia, Universidade Federal do Rio Grande do Norte, 59978-970 Natal, RN, Brazil. smaialima@gmail. com, Dhttps://orcid.org/0000-0001-9365-4879
} 
americanus shows strong site fidelity with a small $(<0.5$ $\mathrm{km}^{2}$ ) activity space (Tilley et al., 2013). Sandbanks and rocky reef are known types of environments for nursery areas of H. americanus (Yokota, Lessa, 2006). The species reproduces annually with maturity ranged from 48 to $56 \mathrm{~cm}$ of disc length (DL) for males and from 64 to $80 \mathrm{~cm}$ of DL for females, corresponding to 3-4 and 5-6 years old respectively (Henningsen, Leaf, 2010; Tagliafico et al., 2013). The gestation of $H$. americanus is between 7-8 months and fecundity from 2 to 7 embryos (Ramírez-Mosqueda et al., 2012). Chapman et al. (2003) described mating behavior in detail, but we are unaware of any detailed ethological studies on the species' foraging behavior. The worldwide conservation status of $H$. americanus is "data deficient" (Grubbs et al., 2016) as well as for the entire Brazilian coast (ICMBio/MMA, 2018), but it was listed a few years ago as "in risk of decline" for the northern and northeastern regions of Brazil (SBEEL, 2005). Dasyatid species are frequently misidentified in Brazilian waters (Schmidt et al., 2015), and being bycatch of trawling, longlines as well as commercial and artisanal fisheries represents the greatest threat for its conservation (SBEEL, 2005; Grubbs et al., 2016).

The biology and ecology of batoids is vastly understudied (e.g., Smith, Merriner, 1985; Ebert, Cowley, 2003; Shibuya et al., 2012; Last et al., 2016) and consequently $\sim 40 \%$ of known ( $\sim 50 \%$ of evaluated) species of batoids are listed as DD in the IUCN Red List (Last et al., 2016; Martins et al., 2018; IUCN, 2019). The scarcity of ethological studies focusing on the feeding aspects of elasmobranch behavior is due, in part, to the inherent difficulty of observing predatory behaviors under natural conditions (Motta, 2004; GarroneNeto, Sazima, 2009; Shibuya et al., 2012; Garla et al., 2017).

Behavioral biology is currently seen as a valuable tool to help prevent biodiversity loss, and it might positively influence environmental decision-making (Buchholz, 2007). In other words, knowing where a species feeds and what can influence its daily behavior may result in management actions, such as protecting a particular site, avoiding some kind of habitat used by humans, as well as specific times of the day or tides. Since many species of elasmobranchs are currently suffering population declines, advancing our knowledge of behavioral biology is imperative (Motta, Wilga, 2001; Grubbs, 2010). According to the International Plan of Action for the Conservation and Management of Sharks (IPOA-Sharks), the conservation of these species depends, in part, on studies of their basic biology and ecology (FAO, 2000). The feeding behavior of chondrichthyan fishes is also of interest from an evolutionary standpoint (Motta, Wilga, 2001) and provides insights on the function and evolution of vertebrate feeding systems (Motta, Wilga, 2001; Motta, 2004). Here, we aim to improve scientific knowledge on the southern stingray, H. americanus (Hildebrand, Schroeder, 1928), through an ethological analysis of its foraging behavior at the Fernando de Noronha Archipelago (FNA), a Marine Protected Area (MPA) and popular tourist attraction in northeast of Brazil (Garla et al., 2015; 2017).
In the FNA, an ontogenetic change occurs in the habitat use of $H$. americanus: smaller individuals typically occupy shallow beach areas with sandy substrates, larger individuals are observed in deeper waters with reef characteristics, and individuals belonging to an intermediate size class are found in both environments (Aguiar et al., 2009). However, it should be pointed out that this can also be influenced by sex, since there is evident sexual dimorphism for this species, with females being larger than males (Henningsen, Leaf, 2010; Tagliafico et al., 2013). Thus, it is quite possible that this ontogenetic and/or sex shift promotes changes in foraging strategies, as the efficiency of certain feeding modes may be habitat-dependent. Therefore, we investigated the effects of ontogeny associated with sex, time of the day, tidal cycle, type of environment and depth on foraging behaviors of $H$. americanus. We also provide, for the first time, a detailed description of the foraging behavior of $H$. americanus.

\section{Material and Methods}

Study area. The study was conducted in the FNA, located in the tropical Western Atlantic (3 $54^{\prime} \mathrm{S}, 32^{\circ} 25^{\prime} \mathrm{W}$ ) approximately $345 \mathrm{~km}$ off the coast of northeastern Brazil (Fig. 1; Eston et al., 1986; Teixeira et al., 2003). Composed of 21 islands, the archipelago comprises an area of $26 \mathrm{~km}^{2}$ and its insular shelf reaches a diameter of $10 \mathrm{~km}$ down to $100 \mathrm{~m}$ isobaths (Teixeira et al., 2003). A great part of the main island $(60-70 \%)$ and its insular shelf of $50 \mathrm{~m}$ isobaths constitute a MPA, where boat traffic, diving, and scientific research are regulated and fishing is prohibited. The remaining portions of the main island and its coastline constitute an Environmental Protection Area (EPA) designated for sustainable use with a local population of about 3,000 people (Garla et al., 2015; 2017). Rocky faces and extensive calcareous algae barriers characterize its southern and southeastern shores. The edges of the northern shore typically have gradual inclinations, with rocky faces and large stones embedded in sand (Eston $e t$ al., 1986). Beach areas are found mostly along the northern shore (Teixeira et al., 2003).

Description of the foraging behavior. Underwater visual surveys (total of $37 \mathrm{~h}$ from 5 to $60 \mathrm{~min}$ a survey) were carried out in July, August, September and December 2007 and January 2008 to develop an ethogram of foraging behaviors through focal-animal follows and ad libitum methods (Lehner, 1998). Sampling was conducted through scuba diving and snorkeling at ten sites (Fig. 1) where $H$. americanus individuals are usually observed performing foraging activities (Aguiar, 2005, Aguiar et al., 2009). Sites of both environments (beach or reef) and substrates (sand or complex, i.e., with gravel, algal turf and calcareous algae) that the target species is typically found were sampled. Reef areas varied from 1 to $21.8 \mathrm{~m}$ in depth and were comprised a soft substrate, a hard substrate or an ecotone covered mostly by gravel, calcareous algae, brown algae and occasionally rocks, sponges and corals. Beach environment with a 
sandy soft substrate ranged in depth from 0.5 to $2 \mathrm{~m}$. All observations were carried out in the daytime with natural lighting (from 10:00 to 17:00 h).

During the underwater surveys, a diver followed a $H$. americanus individual from a close distance of one meter to avoid disturbing the natural behavior of the animal. Each stingray was observed for at least five uninterrupted minutes regardless of its foraging behavior. Stingrays exhibiting foraging behavior (total of $22 \mathrm{~h}$ ) were observed for as long as possible, while observations that lasted less than five minutes were discarded. Similarly, if the individual did not perform any foraging activity within the first $10 \mathrm{~min}$, the survey was abandoned. The foraging behaviors detected and categorized here were based on the assumption that they could culminate in consumption of prey (at least it has to include the phase 3 described in the results). This was done in order to ascertain that the behavior as a whole was a foraging behavior.

Plastic slates were used to record all movement and postures as well as individual sex and DL, local depth, substrate type and environment. Individuals had their DL estimated using a T-shaped ruler (graduated in $5 \mathrm{~cm}$ intervals) placed next to the stingray, as described by Aguiar et al. (2009). Individual stingrays were identified based on estimated size, gender and natural marks during the underwater surveys to avoid following the same individual. Foraging behavior was also recorded using camcorders and still photography ( $10 \mathrm{~h}$ out of $22 \mathrm{~h}$ of foraging behaviors). These digital records were used to confirm and/or better describe a behavior or posture included in the ethogram in addition to avoiding double-counting in the laboratory.

Relationship of environmental features and stingray size with the timing of foraging bouts. Digital records captured during fieldwork were checked in the laboratory in order to measure the duration of foraging events. Foraging bout (according to the ethogram described herein) duration was recorded for each stingray sampled. Mann-Whitney $U$ Test was performed to identify if the duration of the events was significantly different between type of environment (beach or reef) and substrate (sand or complex). Pearson's correlation was used to analyze the relationship between the mean duration of all foraging events performed by an individual and its DL and between the former and the local depth. All statistical procedures here were performed using Statistica 7.0 software (StatSoft Inc., 2007).

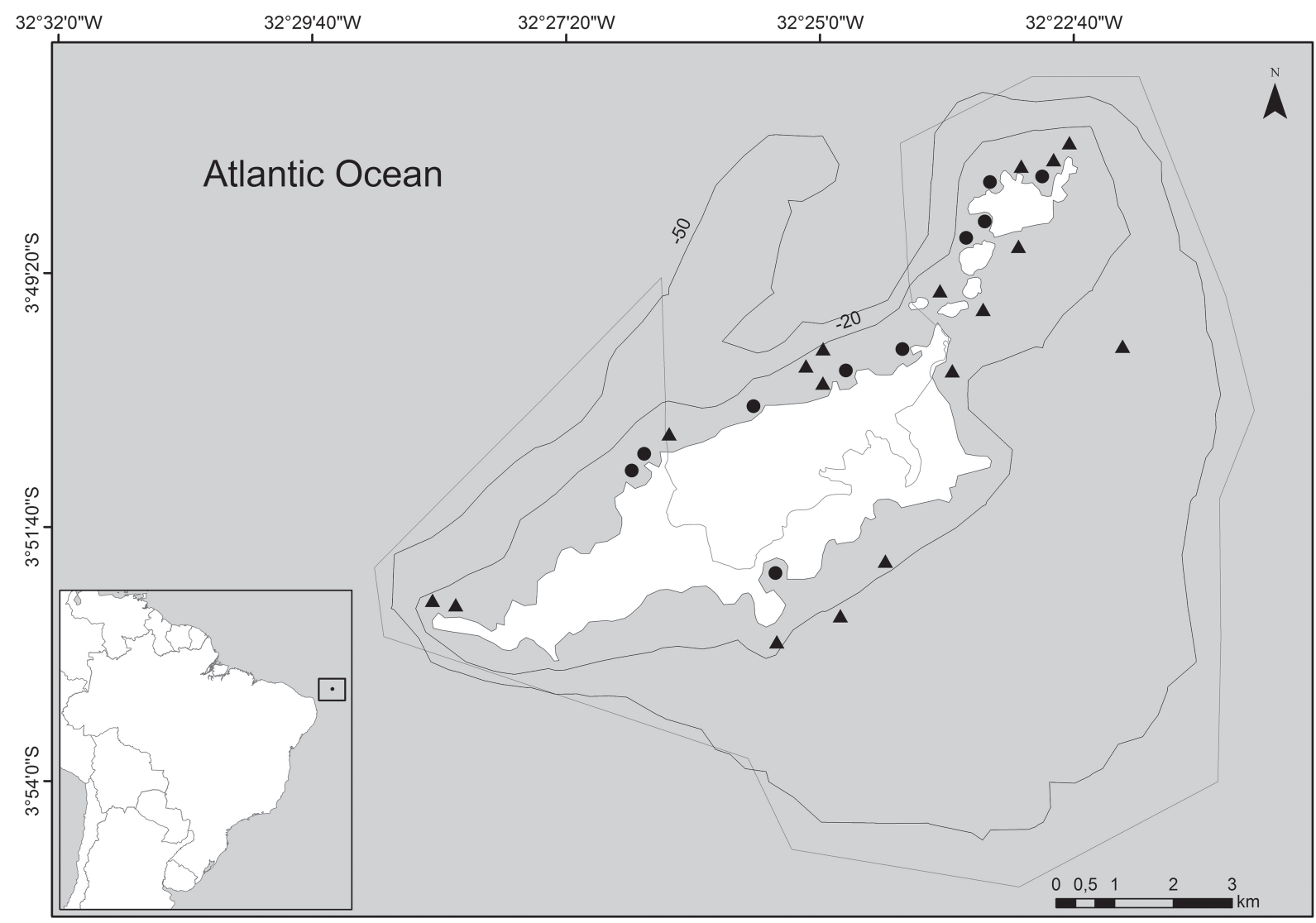

Fig. 1. Map of the study sites in the Fernando de Noronha Arquipelago (FNA). The darker lines indicate the 20m and 50m isobaths. Inside the thinner line, there is the Marine Protected Area (MPA), while outside it, there is the Environmental Protection Area (EPA) for sustainable use. Both areas comprehend the land and insular shelf up to 50m isobaths. Circles indicate the sampling locations where focal-animal, ad libitum and intensive search methods were used; triangles indicate the sampling locations where only the intensive search method was used (see Material and Methods). 
Patterns of foraging activities by time of day and tidal cycle. Diel and tidal patterns of foraging activities were assessed through underwater visual observations conducted during September and October 2006, June, July, August and December 2007 and January, July and August 2008. Surveys were performed while scuba diving and snorkeling at 27 localities (Fig. 1) between 5:00 and 20:00 h. These localities included sandy beaches, reef-associated sandy substrate areas and reef areas. Through an intensive search, the diver performed a roving transect covering a non-overlapping path at a constant speed while recording all $H$. americanus sightings. The frequency of occurrence of individuals performing foraging activities was recorded at different times of the day, as well as during different tidal cycles. The time of day and tidal cycles were divided into categories. A day was divided into five 3-hour periods: dawn (5:00-8:00 h); non-crepuscular periods $(8: 00-11: 00 \mathrm{~h}$, 11:00-14:00 h, 14:00-17:00 h) and dusk (17:00-20:00 h). The tidal cycle was divided into four height phases: low, flood, high and ebb, wherein each phase lasted 3 hours according to the tidal board. All surveys were placed into categories based on the initial time or tidal cycle of the dive.

A stingray was considered to be performing foraging activities when at least one behavior or posture of the four initial phases and, necessarily, some behavior of phase 3 of the ethogram described herein was observed. The sex and DL of $H$. americanus individuals were also noted. All individuals were identified to avoid doublecounting. Goodman's (1965) test compared the proportions between stingrays that were foraging and not foraging in each category (time of day or tidal cycles) as a dependent variable. Goodman's (1964) test provided a comparison of the proportions of stingrays among categories of time of day, as well as among categories of tidal cycles.

The disc length (DL) of all stingrays that could have their sex registered was compared between the sexes by MannWhitney U test, once the data was non-homoscedastic. All tests and analyses were based on a $5 \%$ significance level $(a=0.05)$.

\section{Results}

Throughout all time intervals, females $(N=95 ; 60.95 \pm$ $22.99 \mathrm{~cm}$; mean $\pm \mathrm{SD})$ were bigger $(U=1035.0 ; p<0.001)$ than males $(N=55 ; 42.73 \pm 3.31 \mathrm{~cm})$.

Description of the foraging behavior. A total of 56 individuals were recorded to describe the foraging behavior. Nineteen were observed at beaches, 12 in reef-associated sandy substrate areas and 25 in reef areas. Stingrays with DLs measuring between 15 and $30 \mathrm{~cm}$ were observed mostly at beaches. Individuals ranging from 35 to $65 \mathrm{~cm}$ in DL were most often observed in reef-associated sandy substrate areas varying from 6 to $11 \mathrm{~m}$ in depth. At reef areas, stingrays generally ranged from 30 to $110 \mathrm{~cm}$ in DL.
The ethogram (terms and description) of foraging behavior of $H$. americanus is detailed in Tab. 1. Five main foraging phases with 21 sub-phases (stereotyped behaviors and postures) were identified (Figs. 2-6). The foraging behavior of $H$. americanus was primarily composed of a search for benthic prey above the bottom substrate (Phase 1). This phase is characterized by the swimming or sliding behavior, as if it was scanning the environment, and also comprises the moment of detection and approximation to the potential prey. After that, it settles upon the bottom, which could comprise a smooth or rough landing (Phase 2) to begin its secondary search (Phase 3). This search is like an adjustment of the animal to be able to consume the prey, and the stingray could perform some specific behavior to do this, or wait for some new stimulus and later carry out some other specific behavior of this phase. In order to capture potential prey, the individual displays several behaviors that may or may not involve suction (possible ingestion of a prey item, Phase 4). Only in Phase 4 the stingray could consume a prey. The foraging bout ends when the individual rests or buries itself or even takes-off from the bottom (Phase 5). A complete foraging bout was mandatorily composed of (at least) phases 1, 2, 3 and 5. Moreover, not all behaviors or postures within each phase must be performed.

\section{Qualitative analysis of the occurrence of the sub-phases.}

Some behaviors and postures were exclusive to or performed more often in certain environments or on specific substrate types. Digging (Fig. 4e) and bury (Fig. 6d) were exclusively performed at sandy beaches and reef-associated sandy substrate areas, while jetting water (Fig. 4f), spiracular suction (Fig. 5a), passive inspection (Fig. 4g) and drift take-off (Fig. 6b) were performed more frequently, but not solely, in these environments composed by sandy substrate. Corporeal-spiracular suction (Fig. 5b) was exclusive to reef areas, while turn-back (Fig. 2c), active inspection (Fig. 4h) and active take-off (Fig. 6a) were apparently more common in reef areas, but not restricted to them. Although described in Tab. 1, reverse (Fig. 2d) and rotation (Fig. 2e) were rare regardless of the environment and substrate type. All of the other behaviors and postures seems to be performed evenly among the different environments and substrate types.

In some cases, stingray individuals were observed foraging on vertical reliefs or slopes, such as the hard substrates of rocky shores and great stones at beaches or reef areas. Foraging behaviors in these cases were similar to the ones performed on regular horizontal reliefs of reef areas, but the stingray's body followed the declivity. When stingrays were found foraging over sandy soft substrates, body imprints were frequently observed on the substrate. These body prints presented a contour and size (sometimes used to confirm the size of stingray) similar to the foraging stingray and usually there was a deeper cavity directly below the stingray's mouth and gill slits, which suggests foraging behavior. 
Tab. 1. Ethogram of foraging behavior of Hypanus americanus stingrays. Videos $\mathbf{S 1}$ to $\mathbf{S 1 6}$ are available only as online supplementary files accessed with the online version of the article at http://www.scielo.br/ni).

\begin{tabular}{|c|c|c|}
\hline Foraging phase & Behavior & Description of the behavior \\
\hline \multirow{5}{*}{$\begin{array}{l}\text { Primary search } \\
\text { (Phase 1, Fig. 2) }\end{array}$} & $\begin{array}{l}\text { Active-scanning } \\
\text { (Fig. 2a and video S1) }\end{array}$ & $\begin{array}{l}\text { Swimming just above the bottom }(1-20 \mathrm{~cm}) \text { using undulatory movements of the pectoral fins } \\
\text { while searching for prey. The stingray generates a wave at the margin of the pectoral fins that } \\
\text { begins at the level of the eye and propagates posteriorly. While scanning, the individual's entire } \\
\text { body follows the bottom relief. }\end{array}$ \\
\hline & $\begin{array}{l}\text { Glide-scanning } \\
\text { (Fig. } 2 \mathrm{~b} \text { and video } \mathbf{S 2} \text { ) }\end{array}$ & $\begin{array}{l}\text { Gliding through the water just above the bottom }(1-20 \mathrm{~cm}) \text {, keeping the pectoral fins motionless } \\
\text { while searching for prey. The glide-scanning can be performed due to the inertia of a previous } \\
\text { "active-scanning" or may be due to water flow. While scanning, the individual's entire body } \\
\text { follows the bottom relief. }\end{array}$ \\
\hline & $\begin{array}{l}\text { Turn-back } \\
\text { (Fig. 2c and video } \mathbf{S 3} \text { ) }\end{array}$ & $\begin{array}{l}\text { An abrupt turning maneuver during "active-scanning" or "glide-scanning". Scanning later } \\
\text { continues in the opposite direction. }\end{array}$ \\
\hline & $\begin{array}{l}\text { Reverse } \\
\text { (Fig. 2d and video S4) }\end{array}$ & $\begin{array}{l}\text { Swimming backwards. The stingray shifts the direction of the undulatory movements of its } \\
\text { pectoral fins causing the individual to swim backwards while close to (but not touching) the } \\
\text { bottom. It could happen with some rotation of the body on the dorsal-ventral axis. }\end{array}$ \\
\hline & Rotation (Fig. 2e and video S5) & $\begin{array}{l}\text { Rotating on the dorsal-ventral axis close to the bottom, yet without touching it. The rotation may } \\
\text { be in either direction and take different forms: (i) only one pectoral fin is used in the normal } \\
\text { direction of the undulatory movement; (ii) only one pectoral fin is used in the opposite direction } \\
\text { of normal undulatory movement; (iii) both pectoral fins are used simultaneously, one in the } \\
\text { normal direction and the other in the opposite direction; (iv) the tail is used in association with } \\
\text { other movements. }\end{array}$ \\
\hline \multirow{2}{*}{$\begin{array}{l}\text { Settled upon the } \\
\text { bottom } \\
\text { (Phase 2, Fig. 3) }\end{array}$} & $\begin{array}{l}\text { Smooth-landing } \\
\text { (Fig. 3a and videos } \mathbf{S 3} \text { and } \mathbf{S 6} \text { ) }\end{array}$ & $\begin{array}{l}\text { Stopping and settling smoothly with the margins of the pectoral fins margins touching the bottom. } \\
\text { This probably occurs once prey is detected. }\end{array}$ \\
\hline & $\begin{array}{l}\text { Rough-landing } \\
\text { (Fig. } 3 \mathrm{~b} \text { and video S7) }\end{array}$ & $\begin{array}{l}\text { Stopping suddenly and settling abruptly with the margin of the pectoral fins touching the bottom. } \\
\text { This probably occurs once prey is detected. }\end{array}$ \\
\hline \multirow{8}{*}{$\begin{array}{l}\text { Secondary search } \\
\text { on the bottom } \\
\text { (Phase 3, Fig. 4) }\end{array}$} & $\begin{array}{l}\text { Reverse on the bottom } \\
\text { (Fig. } 4 \mathrm{a} \text { and video } \mathbf{S 8} \text { ) }\end{array}$ & $\begin{array}{l}\text { Moving backwards while touching the bottom. The individual pushes itself against the bottom } \\
\text { with its pectoral fins in order to move backwards with its body still facing forward and/or shifts } \\
\text { the direction of the undulatory movement of the pectoral fins. Pectoral fin movements may be } \\
\text { discrete or obvious. }\end{array}$ \\
\hline & $\begin{array}{l}\text { Rotation on the bottom } \\
\text { (Fig. } 4 \mathrm{~b} \text { and video } \mathbf{S 9} \text { ). }\end{array}$ & $\begin{array}{l}\text { Rotating on the dorsal-ventral axis while touching the bottom. The rotation can be performed } \\
\text { in either direction and may take different forms: (i) the stingray pushes itself against the bottom } \\
\text { with its pectoral fins; (ii) only one pectoral fin is used in the normal direction of the undulatory } \\
\text { movement; (iii) only one pectoral fin is used in the opposite direction of normal undulatory } \\
\text { movement; (iv) the stingray pushes itself against the bottom and both pectoral fins are used } \\
\text { simultaneously, one in the normal direction and the other in the opposite direction; (v) the tail } \\
\text { may also be used in association with other movements. }\end{array}$ \\
\hline & $\begin{array}{l}\text { Short forward displacement } \\
\text { (Fig. } 4 \mathrm{c} \text { and video } \mathbf{S 1 0} \text { ). }\end{array}$ & $\begin{array}{l}\text { Propelling itself forward along a very short distance and then settling back on the bottom. During } \\
\text { this behavior, the individual pushes itself against the bottom with its pectoral fins and/or performs the } \\
\text { normal undulatory pectoral fin movement to move forward for a short distance, as if in a "jump". }\end{array}$ \\
\hline & $\begin{array}{l}\text { Hit the bottom } \\
\text { (Fig. } 4 \mathrm{~d} \text { and video } \mathbf{S 1 1} \text { ) }\end{array}$ & $\begin{array}{l}\text { Propelling itself upright and settling back on the bottom. In this behavior, the individual pushes } \\
\text { itself against the bottom with the pectoral fins, displaying vertical displacement. The stingray may } \\
\text { detach the whole disc or part of it from the floor. }\end{array}$ \\
\hline & $\begin{array}{l}\text { Digging } \\
\text { (Fig. } 4 \mathrm{e} \text { and video } \mathbf{S 1 2} \text { ). }\end{array}$ & $\begin{array}{l}\text { Excavating the substrate. The individual lifts and then lowers its snout. It may also undulate } \\
\text { the margins of the pectoral fins. During this behavior, a large plume of sand is usually observed } \\
\text { around the stingray. }\end{array}$ \\
\hline & $\begin{array}{l}\text { Jetting water } \\
\text { (Fig. } 4 \text { f and videos } \mathbf{S 1 3} \text { and } \mathbf{S 1 4} \text { ). }\end{array}$ & $\begin{array}{l}\text { Jetting water into the substrate. The water is expelled from the mouth and possibly from the gill } \\
\text { slits as well. A plume of sediment is blown forward near the snout. }\end{array}$ \\
\hline & $\begin{array}{l}\text { Passive inspection } \\
\text { (Fig. } 4 \mathrm{~g} \text { and video } \mathbf{S 1 5} \text { ) }\end{array}$ & $\begin{array}{l}\text { Keeping still for a while (completely motionless). The individual's entire body remains on the } \\
\text { bottom over a potential prey item. This normally lasts a few seconds, but may occasionally last } \\
\text { for minutes. }\end{array}$ \\
\hline & $\begin{array}{l}\text { Active inspection } \\
\text { (Fig. } 4 \mathrm{~h} \text { and video } \mathbf{S 1 6} \text { ). }\end{array}$ & $\begin{array}{l}\text { Keeping still for a while with its disc in a convex shape. The individual keeps the pectoral fins } \\
\text { firmly pressed against the bottom, with the scapular region arched upright over a potential prey } \\
\text { item. During this behavior, the tail of the stingray is raised in an angle of about } 30^{\circ} \text {. The stingray } \\
\text { may adjust the margin of the pectoral fins. This behavior normally lasts a few seconds, but may } \\
\text { occasionally last for minutes. }\end{array}$ \\
\hline
\end{tabular}


Tab. 1. (continued)

\begin{tabular}{|c|c|c|}
\hline Foraging phase & Behavior & Description of the behavior \\
\hline \multirow{2}{*}{$\begin{array}{l}\text { Suction } \\
\text { (Phase 4, Fig. 5) }\end{array}$} & $\begin{array}{l}\text { Spiracular suction } \\
\text { (Fig. 5a and video S13). }\end{array}$ & $\begin{array}{l}\text { Taking water and sediment into the mouth while keeping still. The stingray quickly opens and } \\
\text { closes its spiracle and flushes sediment through it. This behavior may occur during "passive } \\
\text { inspection", probably to ingest a prey item. }\end{array}$ \\
\hline & $\begin{array}{l}\text { Corporeal-spiracular suction } \\
\text { (Fig. } 5 \mathrm{~b} \text { and video } \mathbf{S 1 0} \text { ). }\end{array}$ & $\begin{array}{l}\text { Taking water and sediment into the mouth while keeping still with the disc in a convex shape. The } \\
\text { stingray quickly opens and closes its spiracle and flushes sediment through it while lifting and } \\
\text { pressing the entire disc against the bottom. This behavior may occur during "active inspection", } \\
\text { probably to ingest a prey item. }\end{array}$ \\
\hline \multirow{3}{*}{$\begin{array}{l}\text { Final Phase } \\
\text { (Phase 5, Fig. 6) }\end{array}$} & Drift take-off (Fig. 6b). & Detaching from the bottom simply by letting itself drift with the water flow. \\
\hline & Rest (Fig. 6c). & Settling down and keeping still for a long period, completely motionless, on the bottom. \\
\hline & Bury (Fig. 6d). & Burying itself into the substrate. \\
\hline
\end{tabular}

(a)

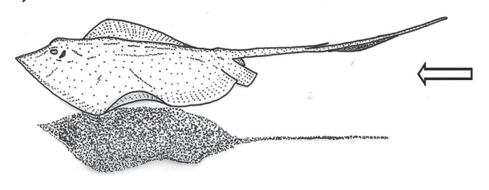

(b)

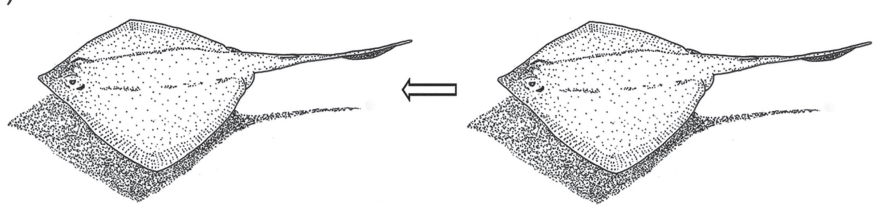

(d)

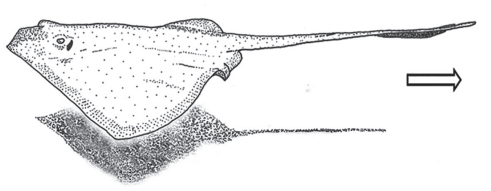

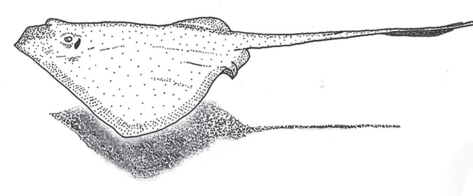
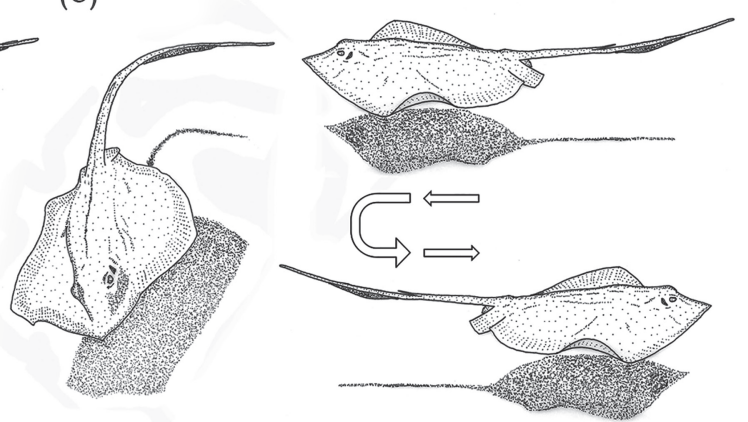

(e)

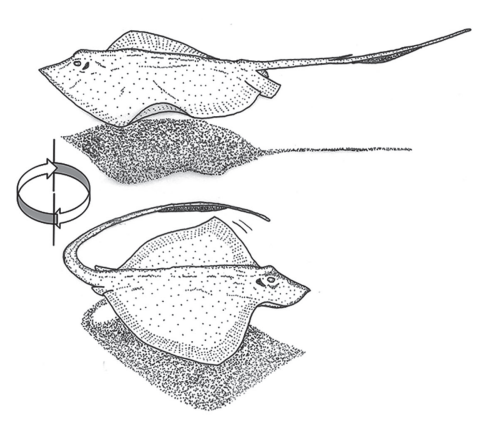

Fig. 2. Illustrations of species-typical patterns of foraging behavior performed by Hypanus americanus in the FNA in phase 1 entitled as primary search. The sub-phases are named as (a) active-scanning; (b) glide-scanning; (c) turn-back; (d) reverse; (e) rotation. The arrow indicates the direction of the movement and in (e) means the rotation on the dorsal-ventral axis of their body. The figures were drawn using original still photographs.

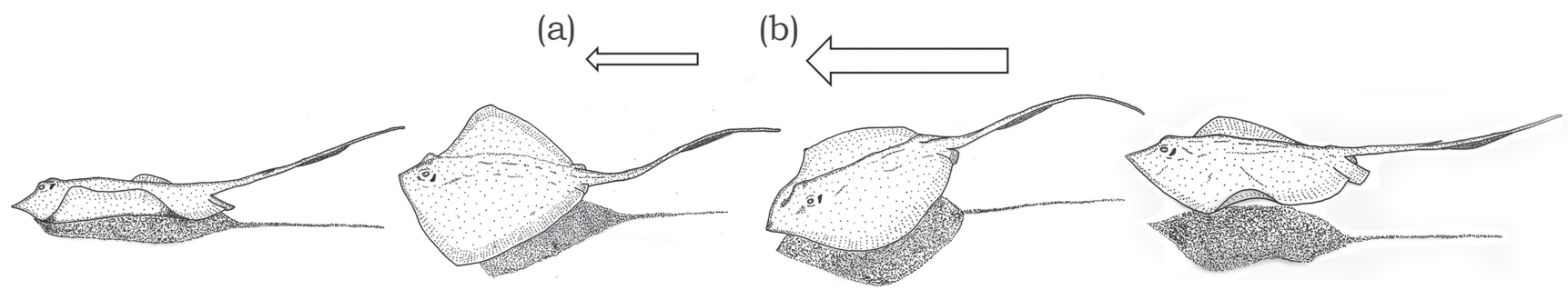

Fig. 3. Illustrations of species-typical patterns of foraging behavior performed by Hypanus americanus in the FNA in phase 2 entitled as settled upon the bottom. The sub-phases are named as (a) smooth-landing (two leftmost drawings); (b) roughlanding (two rightmost drawings). The arrow indicates the direction and the intensity of the movement. Thicker arrow means a more intense and/or abrupt and/or rapid movement. The figures were drawn using original still photographs. 
(a)

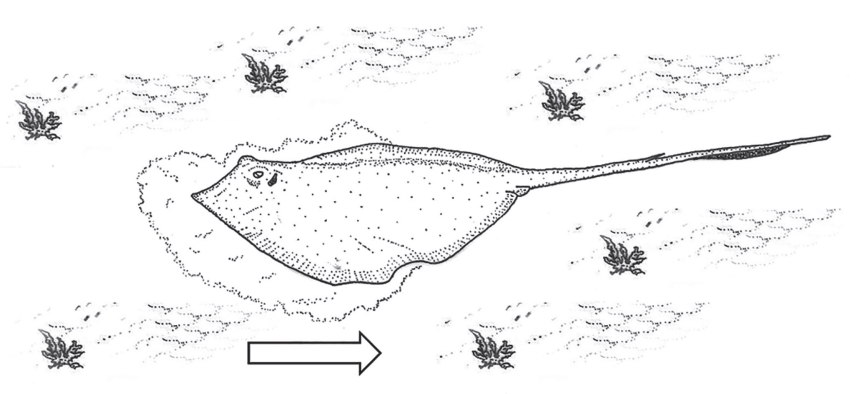

(b)

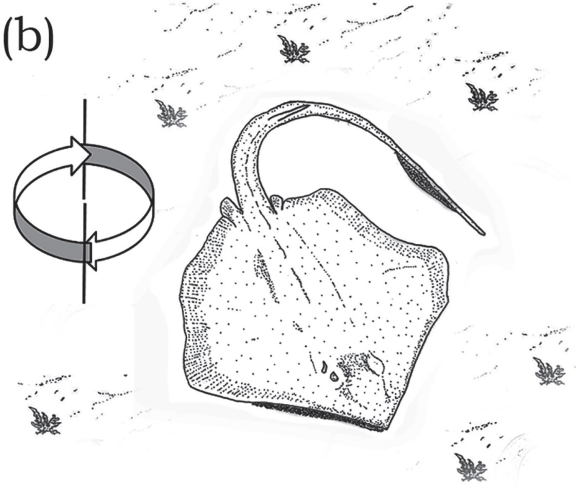

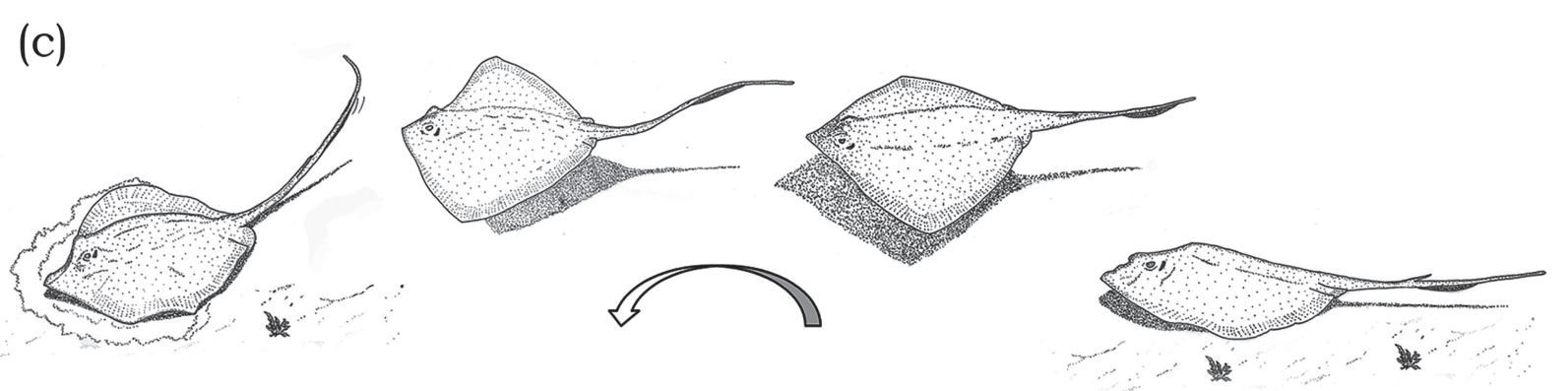

(d)
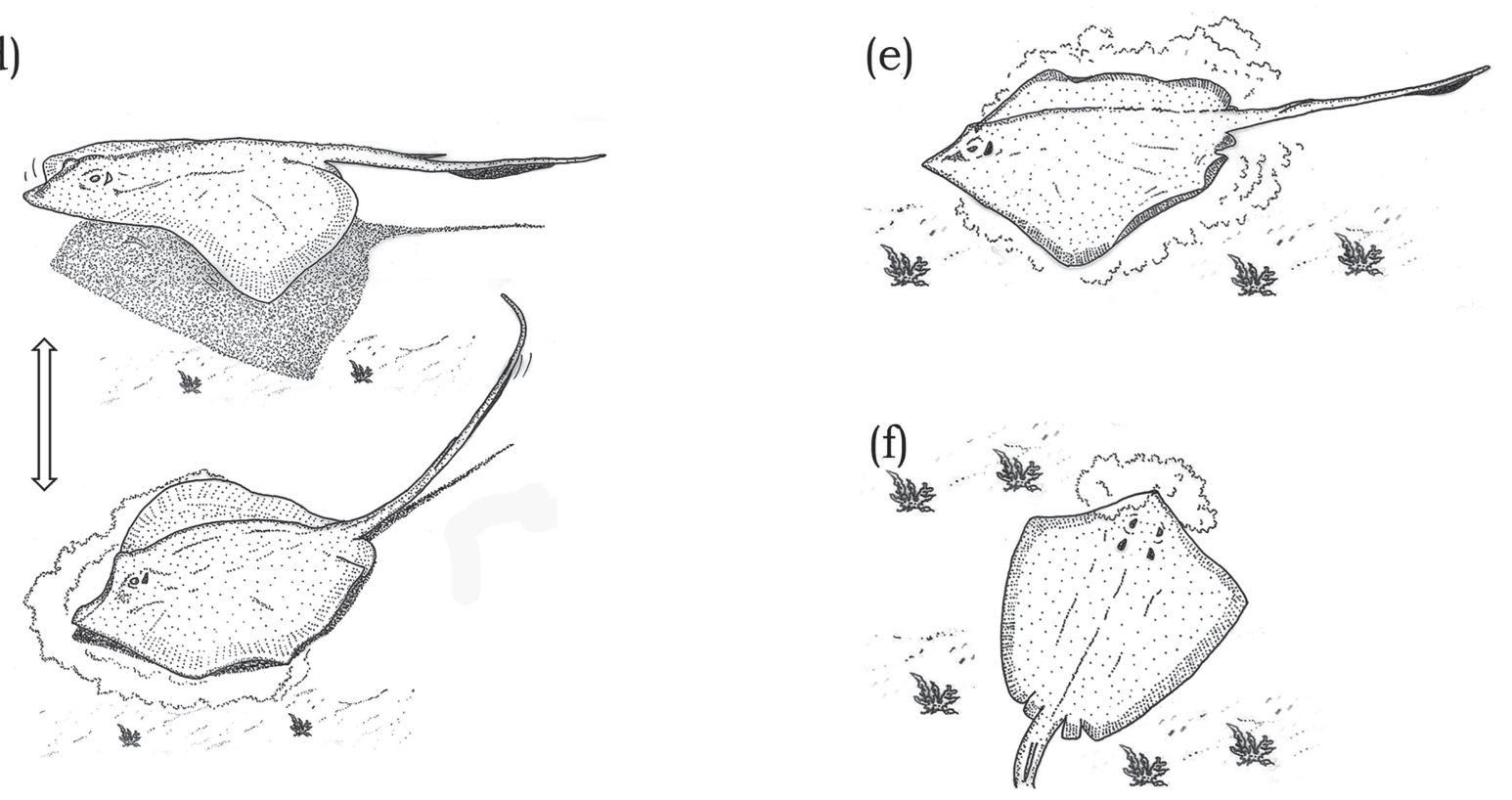

(g)

(h)
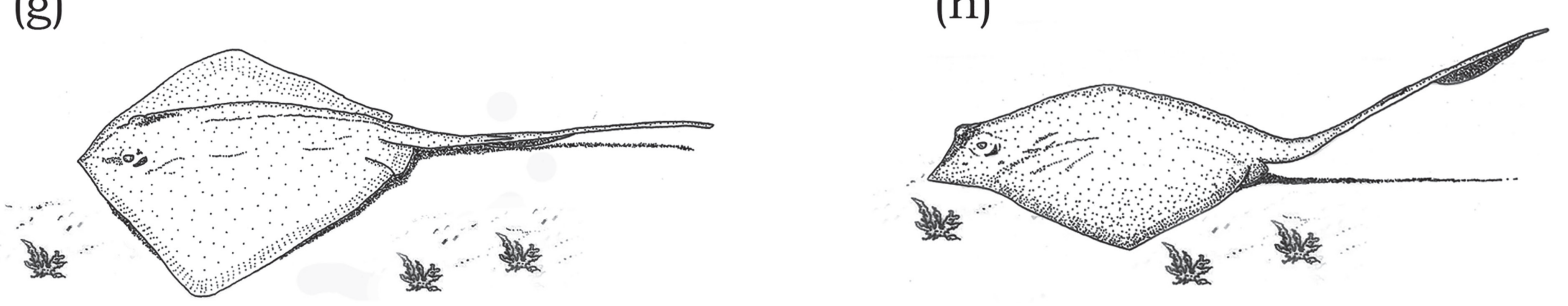

Fig. 4. Illustrations of species-typical patterns of foraging behavior performed by Hypanus americanus in the FNA in phase 3 entitled as secondary search (on the bottom). The sub-phases are named as (a) reverse on the bottom; (b) rotation on the bottom; (c) short forward displacement; (d) hit the bottom; (e) digging; (f) jetting water; (g) passive inspection; (h) active inspection. The arrow indicates the direction of the movement. The figures were drawn using original still photographs. 
(a)

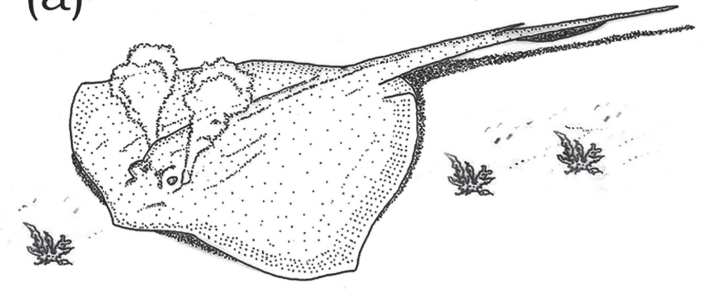

(b)

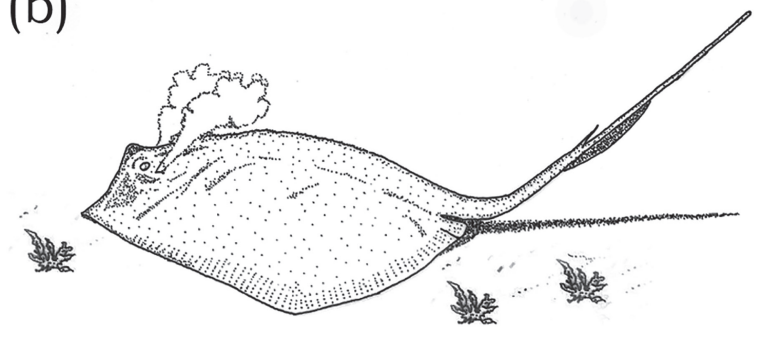

Fig. 5. Illustrations of species-typical patterns of foraging behavior performed by Hypanus americanus in the FNA in phase 4 entitled as suction. The sub-phases are named as (a) spiracular suction; (b) corporeal-spiracular suction. The figures were drawn using original still photographs.

(a)

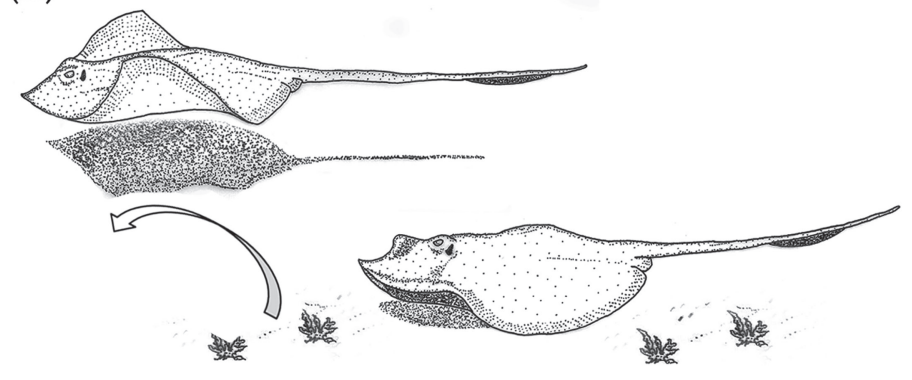

(b)

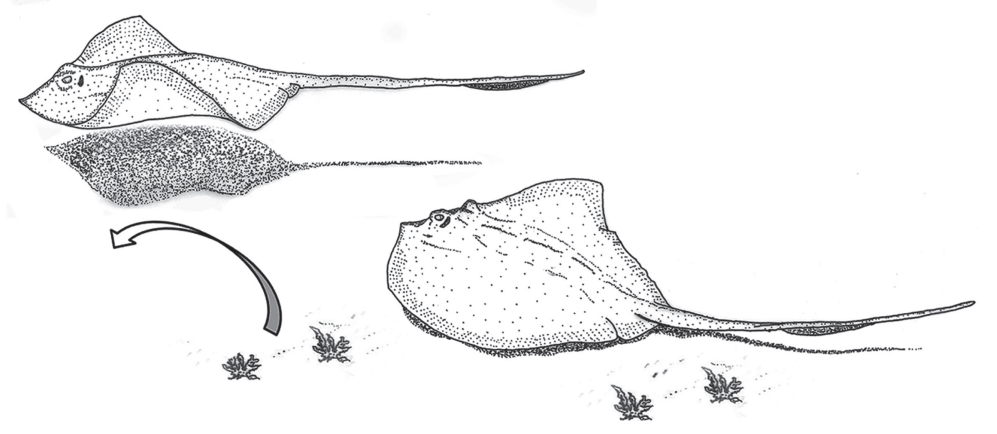

(c)

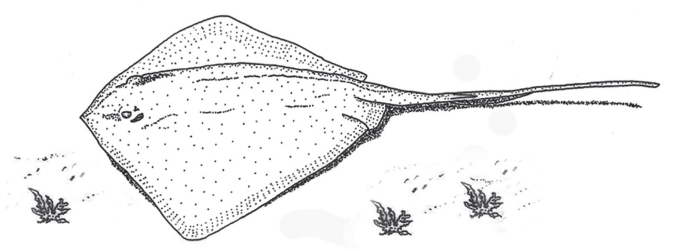

(d)

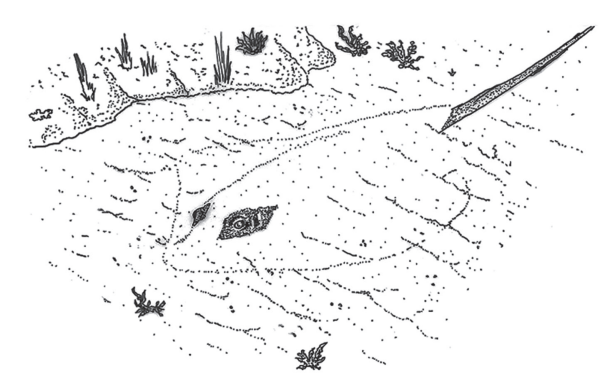

Fig. 6. Illustrations of species-typical patterns of foraging behavior performed by Hypanus americanus in the FNA in phase 5 entitled as final phase. The sub-phases are named as (a) active take-off; (b) drift take-off; (c) rest; (d) bury. The arrow indicates the direction of the movement. The figures were drawn using original still photographs.

We also observed that smaller stingrays, which were sampled mostly in sandy substrate areas (beaches or reef-associated sandy substrate areas), often displayed behaviors common to these environments (as previously described), while larger individuals (mainly females) mostly display behaviors common to reef areas. Nevertheless, we observed that the behavior pattern did not vary among individuals of different sizes and sex when they foraged in similar environments. Thus, smaller specimens displayed a foraging behavior repertoire similar to that performed by their larger conspecifics when foraging in the same kind of environment and vice-versa, as well for both sex.
Relationship of environmental features and stingray size with the timing of foraging bouts. The duration of a foraging bout ( $N=371$ events; encompassing at least the phases 1, 2, 3 and 5 of Tab. 1) varied considerably. The mean time $( \pm \mathrm{SD})$ was $63 \pm 77 \mathrm{~s}$, with a maximum duration of $646 \mathrm{~s}$ and a minimum of $4 \mathrm{~s}$.

Foraging bouts lasted longer in reef areas than in beach regions (Fig. 7a; $U=6056.0 ; p<0.001$ ). Similarly, foraging bouts lasted longer in sites with complex substrates than in sandy areas (Fig. 7b; $U=5115.5 ; p<0.001$ ). Moreover, we found a positive and significant correlation between the duration of foraging bouts and stingray size (Fig. 8a). Although positive, the correlation between the duration of foraging bouts and depth was not significant (Fig. 8b). 

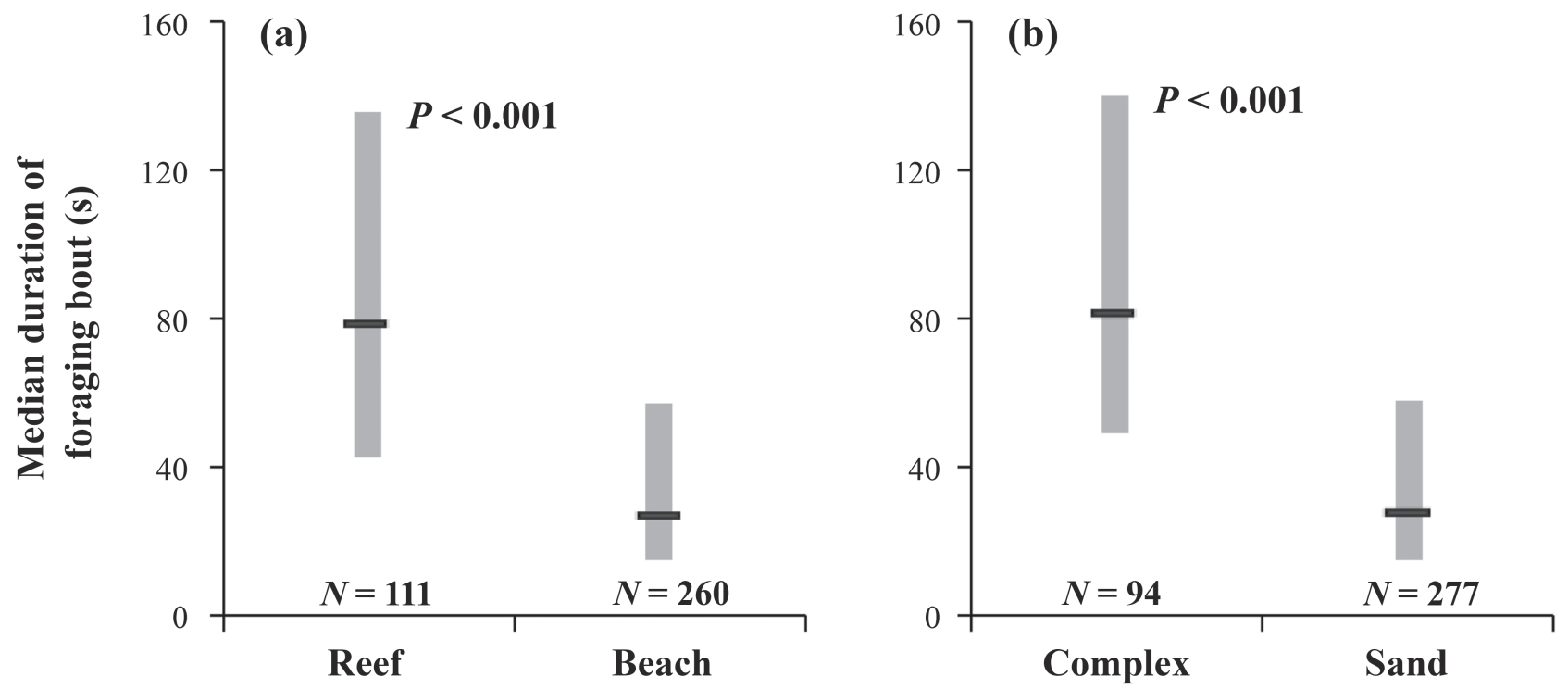

Fig. 7. Duration of median foraging events performed by Hypanus americanus individuals in reef areas and beach regions (a) and in complex (i.e., with gravel, algal turf and calcareous algae) and sandy substrates (b) in the FNA. Gray bars represent first and third quartiles (25-75\% of the data).
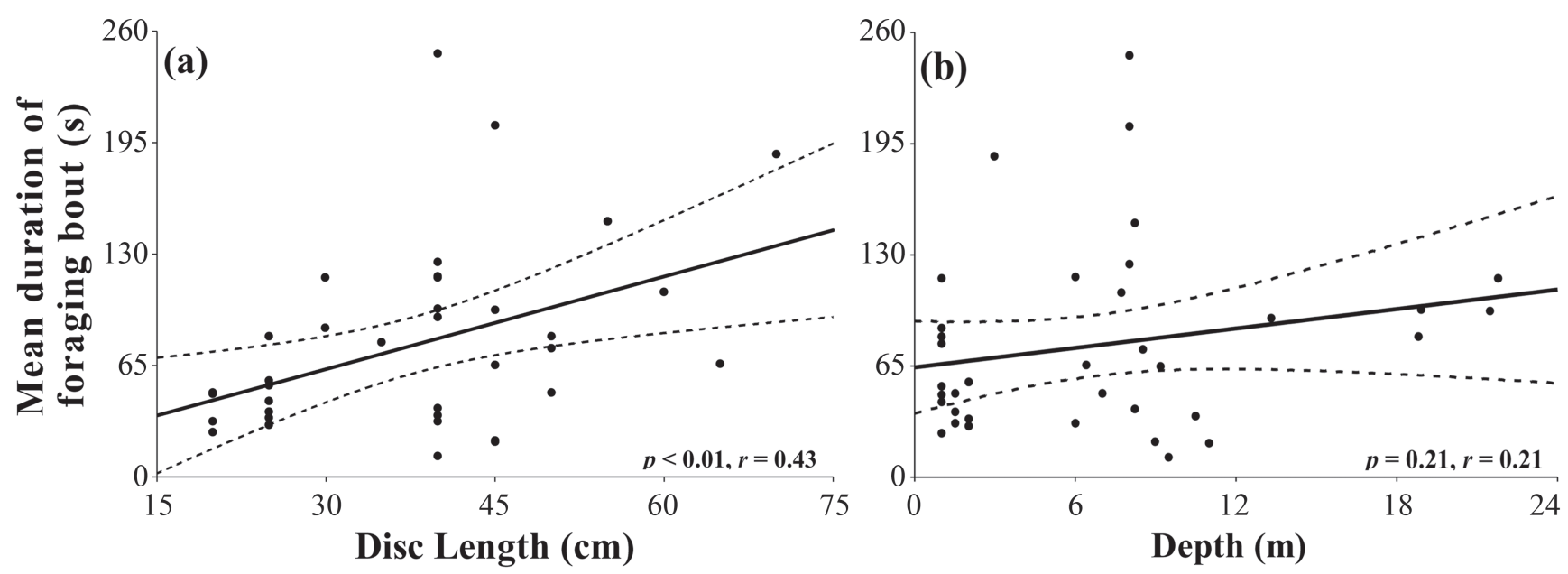

Fig. 8. Person's Correlation between the mean duration of foraging events and the size (disc length) of Hypanus americanus individuals (a) and local depth (b) in the FNA. The interval between dashed lines indicates the confidence interval of the regression line at $p=0.05 . N=37$.

Patterns of foraging activities by time of day and tidal cycle. A total of $79 \mathrm{~h}$ of visual sampling was conducted to assess the diel and tidal patterns of foraging of $H$. americanus. During the surveys, 405 sightings of $H$. americanus were recorded at beaches, reef-associated sandy substrate areas and reef areas with depths ranging from $0.5 \mathrm{~m}$ to $40 \mathrm{~m}$. Both males and females were observed with DLs varying from 15 to $130 \mathrm{~cm}$.

The proportions among all the specimens that were performing foraging activities and all the stingrays that were not foraging were not different, irrespective of tidal cycle. However lower proportions of foraging stingrays were detected in flood and ebb tides (Tab. 2). Both the proportions of stingrays on foraging activity and the ones that were not foraging did not differ among the four tidal cycles (Tab. 2; $G_{\text {calc }}=1.71<G_{\text {crit }}=2.64$; Goodman (1964)'s test; $p>0.05$ ).

The time of day had a significant effect on foraging activities (Tab. 3). In all non-crepuscular times, we observed more non-foraging stingrays, while the proportion among non-foraging stingrays and foraging ones did not differ in dawn and dusk (Tab. 3). In contrast, dusk was the only period that showed more stingrays foraging than not foraging, yet this proportion was not significant. Moreover, in comparison among the time-periods, the proportion of foraging stingrays was higher at dusk than in two non-crepuscular periods (11:00 to 14:00 $\mathrm{h}$ and 14:00 to 17:00 h; Tab. 3). 
Tab. 2. Number of stingrays foraging and not foraging by tidal cycle categories. *indicates significant difference and NS indicates non-significant difference (confidence interval does not include zero for $A_{\text {crit }}=3.84$; Goodman (1965)'s test; $p<$ 0.05 ) in proportions of stingrays that were foraging or not foraging for each tidal cycle category, separately.

\begin{tabular}{lccccc}
\hline \multirow{2}{*}{ Behavior } & \multicolumn{5}{c}{ Tidal cycle } \\
\cline { 2 - 5 } & Low & Flood & High & Ebb & \multirow{2}{*}{ TOTAL } \\
\hline Foraging & $18(40 \%)$ & $68(31 \%)$ & $6(67 \%)$ & $35(26 \%)$ & $127(31 \%)$ \\
Not foraging & $27(60 \%)^{\mathrm{NS}}$ & $148(69 \%)^{*}$ & $3(33 \%)^{\mathrm{NS}}$ & $100(74 \%)^{*}$ & $278(69 \%)^{\mathrm{NS}}$ \\
\hline
\end{tabular}

Tab. 3. Number of stingrays foraging or not foraging by time of the day. *indicates significant difference and ${ }^{\mathrm{NS}}$ indicates non-significant difference (confidence interval does not include zero for $A_{\text {crit }}=3.84$; Goodman (1965)'s test; $p<0.05$ ) in proportions of stingrays that were foraging or not foraging in each time-period. Different lowercase letters denote the difference $\left(G_{\text {calc }}>G_{\text {crit }}=2.81\right.$; Goodman (1964)'s test; $\left.p<0.05\right)$ in proportions of stingray among time-periods (independent variables - multinomial).

\begin{tabular}{lccccc}
\hline \multirow{2}{*}{ Behavior } & Dawn & & Non-crepuscular & \multicolumn{2}{c}{ Dusk } \\
\cline { 2 - 5 } & $5: 00-8: 00 \mathrm{~h}$ & $8: 00-11: 00 \mathrm{~h}$ & $11: 00-14: 00 \mathrm{~h}$ & $14: 00-17: 00 \mathrm{~h}$ & $17: 00-20: 00 \mathrm{~h}$ \\
\hline Foraging & $4(31 \%)^{\mathrm{ab}}$ & $54(36 \%)^{\mathrm{ab}}$ & $13(22 \%)^{\mathrm{b}}$ & $31(22 \%)^{\mathrm{b}}$ & $25(58 \%)^{\mathrm{a}}$ \\
Not foraging & $9(69 \%)^{\mathrm{NS}}$ & $94(64 \%)^{*}$ & $45(78 \%)^{*}$ & $112(78 \%)^{*}$ & $18(42 \%)^{\mathrm{NS}}$ \\
\hline
\end{tabular}

\section{Discussion}

We show herein that the stingray species $H$. americanus performs highly plastic behavior patterns when foraging intermittently throughout the day and in all tide cycles. The proportion of stingrays foraging is attributed to tidal cycle (in ebb and flood tides there were more rays inactive), and time of the day (there were more rays foraging at dusk than in two non-crepuscular periods). Environmental conditions shift the display of particular behavioral repertories, but all stingrays are capable of performing all behaviors, independent of their size and sex. Foraging time increases with habitat complexity, independent of ray size. However, the larger the stingrays, the longer their foraging time, but this may be influenced by the type of environment (larger stingrays were found predominantly in complex environments) and sex (females were bigger than males as previously reported in other studies (Henningsen, Leaf, 2010; Tagliafico et al., 2013)).

Several behaviors described herein are shared among the Myliobatiformes, including other dasyatids (e.g., Bigelow, Schroeder, 1953; Ebert, Cowley, 2003; Motta, 2004; Sasko et al., 2006; Garrone-Neto, Sazima, 2009). Ebert, Cowley (2003) observed that Dasyatis chrysonota (Smith, 1828) also glided close to the bottom while searching for prey, and once prey was detected, their activity was intensified with abrupt sideways and backwards movements until the stingray settled upon the substrate. The behavior of keeping the disc convexly shaped and the tail raised - observed here for H. americanus (Tab. 1: active inspection and corporealspiracular suction) - has also been described by Ebert, Cowley (2003) for individuals expelling sediments via their spiracles. Nevertheless, these authors documented that the pattern of expelling sediments through spiracles and gill slits was due to the suction created by rapid expansion and contraction of the orobranchial chamber, which was not observed in detail for $H$. americanus in the FNA. The ability to expand and contract the orobranchial chamber is observed in elasmobranchs that suction feed (e.g., batoids); this, in turn, helps the predator force prey into the buccal region or excavate it from a burrow (Gregory et al., 1979; Smith, Merriner, 1985; Motta, 2004). Although we cannot confirm that $H$. americanus performs suction feeding on some prey, the spiracular movement accompanied by sediment plumes that was usually observed during the sub-phase of spiracular suction and corporeal-spiracular suction supports this presumption.

In some studies, authors have described stingray individuals capturing and consuming prey (e.g., Ebert, Cowley, 2003; Sasko et al., 2006; Garrone-Neto, Sazima 2009). Here, we prefer to use only the term "suction" rather than "capture" or "consumption". This is due to the inherent difficulty in identifying whether the stingray actually ingested the prey. It was also difficult to identify and distinguish some of the behaviors included in Tab. 1. The behavior of jetting water is difficult to identify when performed in reef areas due to the lack of fine sediment on the substrate. Thus, the typical plume of sediment that is normally ejected forward might not be observed in such situations. The behaviors of passive inspection and rest are equally hard to differentiate, especially in sandy substrate areas. Since it is difficult to visualize prey under natural conditions and because the time each stingray remains motionless while in passive inspection varies somewhat, in some cases it is only possible to differentiate between both behaviors (passive inspection and rest) if the individual shifts to another behavior while under observation. Furthermore, the following performances could be interpreted as the same behavior in certain cases: active and glide scanning; smooth and rough-landing; passive and active inspection; spiracular suction and corporealspiracular suction; active and drift take-off. Nevertheless, we preferred to describe these behaviors as separate units 
because they are clearly carried out in distinct stereotyped body patterns and in different situations (e.g., type of environment and substrate), even though they might have similar functions for the stingray (individual displacement, prey detection and capture).

The behaviors of digging and jetting water described herein have also been documented among other batoids that used these movements to excavate prey buried in soft substrate areas when undulating their pectoral fins (e.g., Bigelow, Schroeder, 1953; Motta, 2004; Sasko et al., 2006; Garrone-Neto, Sazima, 2009). Stokes, Holland (1992), while examining the stomach contents of $H$. americanus, speculated that it excavates lancelets from the sandy substrate. The behavior of jetting water through the mouth and gill slits to dig prey up hydraulically has also been observed for stingray species (Gregory et al., 1979; Smith, Merriner, 1985; Motta, 2004; Sasko et al., 2006). Additionally, authors have noted that a feeding furrow is created in the sediment due to the excavation movements of rays (Gregory et al., 1979; Smith, Merriner, 1985; Motta, 2004; Sasko et al., 2006) that we also observed, probably as a result of digging, jetting water and suction behaviors.

We suggest that the observed patterns might be related to the stingray size, sex, the type of environment and substrate cover of the habitat in which the stingray forages as part of the possible causal mechanisms responsible for $H$. americanus foraging behaviors in the FNA and for the duration of such events. We believe that the behavior of $H$. americanus might be more dependent on environmental conditions rather than species intrinsic fitness of differently sized individuals and sex (e.g., developing special hunting skills or predatory ability during their ontogeny as suggested by Grubbs (2010)). This inference is supported by the fact that behavior did not vary across sizes when they foraged in similar environments. In other words, stingrays of any size and sex can forage by performing the same behaviors in both types of environment. But, as discussed by Aguiar et al. (2009), smaller stingrays (possibly more males) are more associated with sandy beaches and larger (mainly females) ones with rocky reefs. The marked ontogenetic change that occurs in H. americanus's habitat use in the FNA (Aguiar et $a l ., 2009)$ leads to an indirect connection between foraging behavior with stingray size and sex. Similarly, there is a difference in habitat use by different size classes of $D$. chrysonota, which led to different diets between size classes (Ebert, Cowley, 2003). Another explanation for ontogenetic effects on habitat use may be the risk of predation, which has already been described for Rhinoptera bonasus (Mitchill, 1815) (Ajemian, Powers, 2016).

Notwithstanding, it should be noted here that the plasticity and adaptability of its predatory behaviors, which vary according to the environment, contributes to the survival of the species in the FNA. There is great adaptive value for a species using two different environments throughout ontogeny and sex because it reduces the intraspecific competition (Werner, Gilliam, 1984; White et al., 2004; Grubbs, 2010) and size-based segregation by habitat is a considerably notable pattern in the distributions of many species of rays (Grubbs, 2010). It is known to be important for individual survival as the diversity and adaptiveness of predatory behavior may maximize capture success among different habitat types (Tricas, 1985; Motta, Wilga, 2001; Grubbs, 2010). Ethological studies using behavior modification and situation analysis have demonstrated that elasmobranch species are extremely well adapted for detecting and responding to environmental stimuli (Motta, Wilga, 2001; Ajemian et al., 2012; Tilley et al., 2013; Costa et al., 2015). In fact, the diversity of feeding mechanisms found among elasmobranchs is a key feature of their evolutionary success as predators in marine ecosystems (Tricas, 1985) and stingrays are versatile colonizers of bottom habitats and are capable of precise maneuvering across the substrate (Compagno, 1990).

The extrinsic environmental factors (such as substrate complexity and water flow) influence the behavioral repertoire of $H$. americanus in the FNA. For example, the behaviors of digging and jetting water are frequently performed on sandy soft substrates where potential prey might be buried. In addition, the active inspection and corporeal-spiracular suction behaviors are frequently observed in reef areas. We speculate that this happens because the stingray has to keep its pectoral fins firmly pressed against the substrate with the scapular region arched upright to form an enclosure around a potential prey hidden in an irregular substrate as previously documented for other batoid species (Dean, Motta, 2004). In addition, the glide-scanning and drift take-off behaviors are more frequent in beaches because it is easier to be performed under the influence of waves and water flow. Thus, based on these observations, we concluded that the species of $H$. americanus in the FNA could modulate its repertoire of foraging behaviors according to substrate complexity and water flow.

Although both environments (sandy beaches and reefs) can support rays of different sizes, sex and different behaviors and durations thereof, there is a clear need for conservation of both for this species. This is because both environments are already reported as nursery areas for this species on the coast of Northeastern Brazil (Yokota, Lessa, 2006). A similar multi-habitat conservation approach was also suggested for Hypanus marianae (Gomes, Rosa, Gadig, 2000) based on the same ontogenetic pattern of habitat use (Costa et al., 2015) and it is particularly important for the sandy beaches that receive little mention of protection, but are quite affected by fisheries and pollutants (Curran et al., 2002; Costa et al., 2015).

Concerning diel patterns for foraging activities of $H$. americanus, we suggest that this species forages intermittently throughout the day in the FNA. Nevertheless, they are less active during non-crepuscular periods, and commonly increase feeding activity at dusk. Although this finding might suggest that foraging behavior continues 
nocturnally, we frequently (almost all sightings) observed $H$. americanus laying on the bottom at night or in a low activity behavior in the FNA. Conversely, $H$. americanus are more active in the daytime in the Glover Reef Atoll (Tilley et al., 2013) and individuals from non-tourist sites are more active at night, while it shifts to diurnal behavior at tourist sites in response to the "provisioned food" supplied by tourists in the Grand Cayman (Corcoran et al., 2013). We also suggest that $H$. americanus also forages intermittently throughout tidal cycles, but are less active during flood and ebb tides. Our findings agree with Gilliam, Sullivan (1993), who reported that $H$. americanus feeds continuously throughout the day and prefers to feed during the high tide in the Bahamas. It is probably due to greater prey availability in the Bahamas and the FNA, regardless of time of the day, and also because of increased availability of foraging habitat at high tide (Cartamil et al., 2003). As H. americanus is an opportunistic mesopredator (Gilliam, Sullivan 1993) that could also prey on other dasyatids (Branco-Nunes et al., 2016), this species probably shifts its foraging behavior according to time of the day, environment and tide and it could differ among sites of their occurrences.

Finally, we must highlight that $H$. americanus in the FNA is exposed all year round to marine tourist activities, but does not usually seem to alter its natural behavior in the presence of divers. However, we cannot assume that the foraging behaviors described here closely represent the natural pattern of the species because stingrays in the FNA could be accustomed to the presence of divers and such effects can only be assessed if compared to another non-tourist region with similar environmental features. Regardless, as this species can be very important, even economically, in sites of ecotourism activities (Vaudo et al., 2018) such as the FNA, the proper management of these activities is necessary and deserves further attention.

\section{Acknowledgements}

This study was partly funded by grants from the following Brazilian agencies: CAPES/MEC, CNPq and FAPERJ. We are grateful to the Instituto Chico Mendes, APA and PARNAMAR Fernando de Noronha and Administração do Distrito Estadual de Fernando de Noronha for field-trip support and for issuing permits that allowed us to work in the FNA. We would also like to thank the following diving centers: Noronha Divers, Atlantis Divers and Águas Claras for operational diving support. Lastly, we would like to thank Janaina Machado and Tatiana Leite for their aid during fieldwork. Gratitude is expressed to all anonymous reviewers and Joana Aguiar (English Proofreading), who contributed to improve substantially the manuscript, and Alyson Cavalcante for contrast digital adjustment in the figures of stingray's behavior. This paper is part of Aguiar's $\mathrm{PhD}$ thesis, which was developed at the Universidade Federal do Rio de Janeiro and supported by CAPES/MEC. SMQL received CNPq research productivity grant (313644/2018-7).

\section{References}

Aguiar AA. Estrutura e densidade populacional e uso do habitat por Dasyatis americana Hildebrand e Schroeder (1928) (Chondrichthyes: Dasyatidae) no Arquipélago de Fernando de Noronha, Brasil. [MSc Thesis]. João Pessoa, PB: Universidade Federal da Paraíba; 2005.

Aguiar AA, Valentin JL, Rosa RS. Habitat use by Dasyatis americana in a south-western Atlantic oceanic island. J Mar Biol Assoc UK. 2009; 89(6):1147-52.

Ajemian MJ, Powers SP, Murdoch TJT. Estimating the potential impacts of large mesopredators on benthic resources: integrative assessment of spotted eagle ray foraging ecology in Bermuda. PloS One. 2012; 7(7):e40227.

Ajemian MJ, Powers SP. Seasonality and ontogenetic habitat partitioning of cownose rays in the Northern Gulf of Mexico. Estuaries Coasts. 2016; 39(4):1234-48.

Bigelow HB, Schroeder WC. Fishes of the Western North Atlantic. New Haven, Peabody of Natural History, Yale University; 1953. pt. 2, Sawfishes, guitarfishes, skates and rays. (Memoir sears foundation for marine research; no. 1).

Branco-Nunes ISL, Albuquerque FV, Nunes DM, Oliveira PGV, Hazin FHV. First record of predation between Dasyatis species. J Fish Biol. 2016; 89(4):2178-81.

Buchholz R. Behavioral biology: an effective and relevant conservation tool. Trends Ecol Evol. 2007; 22(8):401-07.

Cartamil DP, Vaudo JJ, Lowe CG, Wetherbee BM, Holland KN. Diel movement patterns of the Hawaiian stingray, Dasyatis lata: implications for ecological interactions between sympatric elasmobranch species. Mar Biol (Heidelberg, Ger). 2003; 142(5):841-47.

Chapman DD, Corcoran MJ, Harvey GM, Malan S, Shivji MS. Mating behavior of southern stingrays, Dasyatis americana (Dasyatidae). Environ Biol Fishes. 2003; 68(3):241-45.

Compagno LJV. Alternative life-history styles of cartilaginous fishes in time and space. Environ Biol Fishes. 1990; 28(1-4):33-75.

Corcoran MJ, Wetherbee BM, Shivji MS, Potenski MD, Chapman DD, Harvey GM. Supplemental feeding for ecotourism reverses diel activity and alters movement patterns and spatial distribution of the southern stingray, Dasyatis americana. PloS One. 2013; 8(3):e59235.

Costa TLA, Thayer JA, Mendes LF. Population characteristics, habitat and diet of a recently discovered stingray Dasyatis marianae: implications for conservation. J Fish Biol. 2015; 86(2):527-43.

Curran S, Kumar A, Lutz W, Williams M. Interactions between coastal and marine ecosystems and human population systems: perspectives on how consumption mediates this interaction. Ambio. 2002; 31(4):264-68.

Dean MN, Motta PJ. Feeding behavior and kinematics of the lesser electric ray, Narcine brasiliensis (Elasmobranchii: Batoidea). Zoology (Jena). 2004; 107(3):171-89.

Ebert DA, Cowley PD. Diet, feeding behaviour and habitat utilisation of the blue stingray Dasyatis chrysonota (Smith, 1828) in South African waters. Mar Freshwater Res. 2003; 54(8):957-65. 
Eston VR, Migotto AE, Oliveira Filho EC, Rodrigues SA, Freitas JC. Vertical distribution of benthic marine organisms on rocky coasts of Fernando de Noronha Archipelago (Brazil). Bol Inst Oceangr (Univ São Paulo). 1986; 34:37-53.

FAO. Fisheries management. Rome: FAO; 2000, pt. 1, Conservation and management of sharks. (FAO Technical Guidelines for Responsible Fisheries; 4).

Garla RC, Freitas RHA, Calado JF, Paterno GBC, Carvalho AR. Public awareness of the economic potential and threats to sharks of a tropical oceanic archipelago in the western South Atlantic. Mar Policy. 2015; 60:128-33.

Garla RC, Gadig OBF, Junior JG, Veras LB, Garrone-Neto D. Hunting tactics of the lemon shark, Negaprion brevirostris, in shallow waters of an oceanic insular area in the western equatorial Atlantic. Neotrop Ichthyol. 2017; 15(1):e160119.

Garrone-Neto D, Sazima I. Stirring, charging, and picking: hunting tactics of potamotrygonid rays in the upper Paraná River. Neotrop Ichthyol. 2009; 7(1):113-16.

Gilliam D, Sullivan KM. Diet and feeding habits of the southern stingray Dasyatis americana in the Central Bahamas. Bull Mar Sci. 1993; 52(3):1007-13.

Goodman LA. Simultaneous confidence intervals for contrasts among multinomial populations. Ann Math Stat. 1964; 35(2):716-25.

Goodman LA. On simultaneous confidence intervals for multinomial proportions. Technometrics. 1965; 7(2):247-54.

Gregory MR, Balance PF, Gibson GW, Ayling AM. On how some rays (Elasmobranchia) excavate feeding depressions by Jetting Water. J Sediment Petrol. 1979; 49(4):1125-29.

Grubbs RD. Ontogenetic shifts in movements and habitat use. In: Carrier JC, Musick JA, Heithaus MR, editors. Sharks and their relatives II: biodiversity, adaptive physiology, and conservation. 1st ed. New York: Taylor \& Francis Group; 2010. p.319-350.

Grubbs RD, Snelson FF, Piercy A, Rosa R, Furtado M. Hypanus americanus. The IUCN Red List of threatened species [Electronic version]; 2016. Available from: http://dx.doi. org/10.2305/IUCN.UK.2016-3.RLTS.T60149A104123038.en

Henningsen AD, Leaf RT. Observations on the captive biology of the southern stingray. Trans Am Fish Soc. 2010; 139(3):783-91.

Instituto Chico Mendes de Conservação da Biodiversidade/ Ministério do Meio Ambiente (ICMBio/MMA). Livro vermelho da fauna brasileira ameaçada de extinção. 1st ed. Brasília, DF: ICMBio/MMA; 2018. vol. 1.

International Union for Conservation of Nature (IUCN). The IUCN Red List of threatened species. Version 2018-2 [Internet]. 2019. Available from: http://www.iucnredlist.org

Last PR, White WT, Carvalho MR, Séret B, Stehmann MFW, Naylor GJP. Rays of the world. 1st ed. Melbourne: Csiro Publishing; 2016.

Lehner PN. Handbook of ethological methods. 2nd ed. Cambridge: Cambridge University Press; 1998.

Martins APB, Heupel MR, Chin A, Simpfendorfer CA. Batoid nurseries: definition, use and importance. Mar Ecol Prog Ser. 2018; 595:253-267.
Menni RC, Stehmann MFW. Distribution, environment and biology of batoid fishes off Argentina, Uruguay and Brazil. A review. Rev Mus Argent Cienc Nat, n. s. 2000; 2(1):69-109.

Motta PJ. Prey capture behavior and feeding mechanics of elasmobranchs. In: Carrier JC, Musick JA, Heithaus MR, editors. Biology of sharks and their relatives. Boca Raton: CRC Press: 2004. p.165-202.

Motta PJ, Wilga CD. Advances in the study of feeding behaviors, mechanisms, and mechanics of sharks. Environ Biol Fishes. 2001; 60(1-3):131-56.

Ramírez-Mosqueda E, Pérez-Jiménez JC, Mendoza-Carranza M. Reproductive parameters of the southern stingray Dasyatis americana in southern gulf of Mexico. Lat Am J Aquat Res. 2012; 40(2):335-44.

Sasko DE, Dean MN, Motta PJ, Hueter RE. Prey capture behavior and kinematics of the Atlantic cownose ray, Rhinoptera bonasus. Zoology (Jena). 2006; 109(3):171-81.

Sociedade brasileira para o estudo de elasmobrânquios (SBEEL). Plano nacional de ação para a conservação e o manejo dos estoques de peixes elasmobrânquios no Brasil. SBEEL: Recife. 2005.

Semeniuk CAD, Rothley KD. Costs of group-living for a normally solitary forager: effects of provisioning tourism on southern stingrays Dasyatis americana. Mar Ecol Prog Ser. 2008; 357:271-82.

Schmidt BF, Amorim AF, Hilsdorf AWS. PCR-RFLP analysis to identify four ray species of the genus Dasyatis (Elasmobranchii, Dasyatidae) fished along the southeastern and southern coast of Brazil. Fish Res. 2015; 167:71-74.

Shibuya A, Zuanon J, Tanaka S. Feeding behavior of the Neotropical freshwater stingray Potamotrygon motoro (Elasmobranchii: Potamotrygonidae). Neotrop Ichthyol. 2012; 10(1):189-96.

Smith JW, Merriner JV. Food habits and feeding behavior of the cownose ray, Rhinoptera bonasus, in Lower Chesapeake Bay. Estuaries. 1985; 8(3):305-10.

Soto JMR. Peixes do Arquipélago de Fernando de Noronha. Mare Magnum. 2000; 1(2):147-69.

Statsoft, Inc. Electronic Statistics Textbook. Available from: http:// www.statsoft.com/textbook/stathome.html

Stokes MD, Holland ND. Southern stingray (Dasyatis americana) feeding on lancelets (Brachiostoma floridae). J Fish Biol. 1992; 41(6):1043-44.

Tagliafico A, Rago N, Rangel MS. Biological aspects of rays Dasyatis guttata and Dasyatis americana (Myliobatiformes: Dasyatidae) caught by the artisanal fishery in Margarita Island, Venezuela. Rev Biol Mar Oceanogr. 2013; 48(2):365-73.

Teixeira W, Cordani UG, Menor EA. Caminhos do Tempo Geológico. In: Linsker R, editor. Arquipélago de Fernando de Noronha: o paraíso do vulcão. São Paulo: Terra Virgem Editora; 2003. p.26-63.

Tilley A, López-Angarita J, Turner JR. Effects of scale and habitat distribution on the movement of the southern stingray Dasyatis americana on a Caribbean atoll. Mar Ecol Prog Ser. 2013; 482:169-79.

Tricas TC. Feeding ethology of the white shark, Carcharodon carcharias. Memoirs. 1985; 9:81-91. 
Vaudo JJ, Wetherbee BM, Harvey GCM, Harvey JC, Prebble AJF, Corcoran MJ et al. Characterisation and monitoring of one of the world's most valuable ecotourism animals, the southern stingray at Stingray City, Grand Cayman. Mar Freshw Res. 2018; 69(1):144-54.

Werner EE, Gilliam JF. The ontogenetic niche and species interactions in size-structured populations. Annu Rev Ecol Syst. 1984; 15:393-425.

White WT, Platell ME, Potter IC. Comparisons between the diets of four abundant species of elasmobranch in a subtropical embayment: implications for resource partitioning. Mar Biol (Heidelberg, Ger). 2004; 144(3):439-48.
Yokota L, Lessa RP. A nursery area for sharks and rays in Northeastern Brazil. Environ Biol Fishes. 2006; 75(3):349-60.

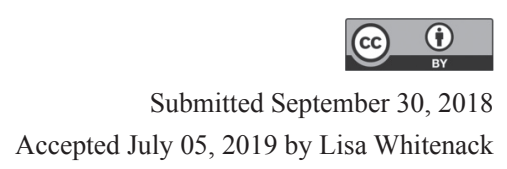

